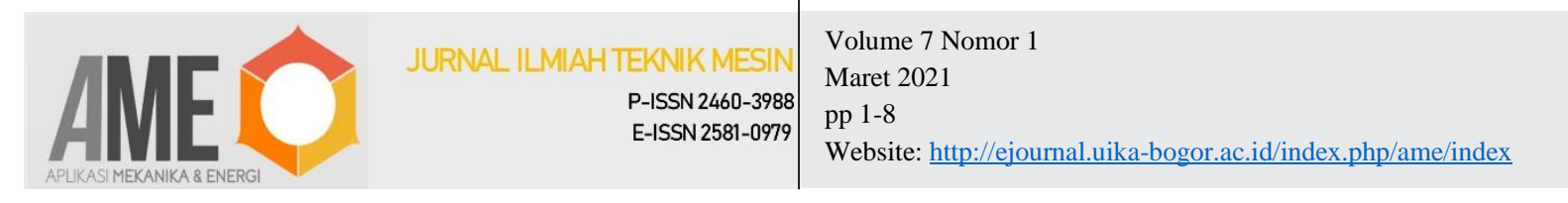

\title{
PENGEMBANGAN WOOD PLASTIC COMPOSITE (WPC) MELALUI PEMANFAATAN LIMBAH PLASTIK DAN SERBUK GERGAJI KAYU
}

\author{
Roy Waluyo $^{1 *}$,Anton Royanto Ahmad ${ }^{1}$, Gatot Eka Pramono ${ }^{1}$, Kurniansyah ${ }^{1}$ \\ ${ }^{1}$ Fakultas Teknik dan Sains, Universitas Ibn Khaldun Bogor, Indonesia, 16161
}

\begin{abstract}
ABSTRAK
Dalam penelitian ini telah dilakukan pembuatan wood plastic composite (WPC) melalui pemanfaatan limbah plastik dan serbuk gergaji kayu (SGK). Plastik yang digunakan adalah HDPE. Material lain yang ditambahkan secara konstan adalah serat serabut kelapa (SSK) sebanyak 2\% Selanjutnya WPC dikarekterisasi. Proses pembuatan menggunakan proses hot press. Ukuran sampel adalah $200 \mathrm{~mm} \mathrm{x}$ $100 \mathrm{~mm} \times 11 \mathrm{~mm}$. Pengujian tarik mengikuti standar ASTM D639 dan pengujian impak mengikuti standar ASTM D6110. Penelitian ini bertujuan untuk mendapatkan pengaruh presentasi SGK, tekanan pencetakan dan ukuran mesh SGK terhadap sifat mekanis (kekuatan tarik dan impak) dari WPC. Hasil pengujian menunjukan, penambahan sebuk gergaji meningkatkan kekuatan tarik dari WPC. Sampel WPC dengan 20\% SGK memiliki kekuatan tarik rata-rata terbesar yaitu 6,67 MPa. Kekuatan impak terbesar terdapat pada sampel WPC dengan 20\% SGK yang memiliki harga rata-rata terbesar yaitu 0,237 Joule/ $\mathrm{mm}^{2}$. Kekuatan tarik maksimum pada variasi beban, terdapat pada beban $100 \mathrm{~kg}$ atau pada tekanan $4.5 \mathrm{~kg} / \mathrm{cm}^{2}$, dengan nilai kekuatan tarik sebesar $10 \mathrm{MPa}$. kekuatan tarik meningkat seiring menurunnya ukuran butir serbuk gergaji. Kekuatan tarik terbesar diperoleh pada sampel WPC yang memiliki mesh 30 yaitu sebesar $9 \mathrm{MPa}$.
\end{abstract}

Kata kunci: HDPE; serbuk gergaji kayu; Wood Plastic Composite

\begin{abstract}
In this study, wood plastic composite (WPC) has been manufactured through waste plastic and coconut wood sawdust (CWS). The plastic used is HDPE. Another material was continuously adding 2\% coconut fiber $(C F)$. Furthermore, WPC was characterized. The manufacture process used a hot press process. The sample size was $20 \mathrm{~mm} \times 60 \mathrm{~mm} \times 10 \mathrm{~mm}$. Tensile testing follows the ASTM D639 standard and impact testing follows ASTM D6110 standard. This study aims to determine the effect of CWS ratio, casting pressure, and CWS mesh size on WPC's mechanical properties (tensile strength and impact). The test results showed that the addition of a saw increased the tensile strength of the WPC. WPC sample with $20 \% \mathrm{CWS}$ has the most considerable average tensile strength, namely $6.67 \mathrm{MPa}$. The most significant impact strength was found in the WPC sample, with 20\% CWS as the most considerable average price, namely 0.237 Joules / $\mathrm{mm} 2$. The maximum tensile strength at load variation found at a load of $100 \mathrm{~kg}$ (pressure of $4.5 \mathrm{~kg} / \mathrm{cm}^{2}$ ), with a tensile strength value of $10 \mathrm{MPa}$. The tensile strength increased as the sawdust grain size decreased. The greatest tensile strength was obtained in 30 mesh of the WPC sample which was $9 M P a$.
\end{abstract}

Keywords: HDPE; Sawdust; Wood Plastic Composite

\footnotetext{
* Penulis korespondensi

Email: roy.waluyo@uika-bogor.ac.id

Diterima 15 September 2020; Penerimaan hasil revisi 14 Oktober 2020; Disetujui 7 November 2020

Tersedia online 1 Maret 2021

AME (Aplikasi Mekanika dan Energi): Jurnal Ilmiah Teknik Mesin @ 2021
} 


\section{PENDAHULUAN}

Produksi sampah di Indonesia sudah sangat menghawatirkan. Menurut direktur pengelolaan sampah Kementerian Lingkungan Hidup dan Kehutanan (KLHK) "produksi sampah nasional mencapai sekitar 65,8 juta ton pertahunnya dimana 16 persennya adalah sampah plastik" (Republika, 2018). Hasil penelitian Jenna R. Jambeck, Indonesia tercatat jadi pencemar sampah plastik ke lautan global kedua terbesar setelah Cina. Setiap tahun sekitar 3 juta ton sampah plastik Indonesia masuk ke lautan. Juga berbagai sungai dan kawasan pantai kini dipenuhi sampah yang sangat sulit terurai (JR et al., 2015).

Salah satu upaya pemanfaatan limbah plastik adalah melalui pembuatan wood plastic composite (WPC). WPC adalah Polymer Matriks Composite berupa campuran antara plastik sebagai matriks atau filler dan kayu (berupa serbuk atau serat) sebagai penguat (reinforced). Untuk polymer jenis termoplastik penyatuan campuran material membutuhkan temperatur dan tekanan. Seperti pada pencetakan dengan proses hotpress (Slamet, 2013) (Nurwendi, Simpen, \& Negara, 2016) dan injection molding (Gurau \& Ayrilmis, 2018) (Bledzki, Mamun, \& Volk, 2010) atau proses pembuatan tanpa tekanan seperti layup (Yudhyadi \& Sari, 2013).

Studi tentang karakteristik WPC telah banyak dilakukan. WPC dikembangkan menggunakan berbagai jenis pasangan plastik-kayu, diantaranya; Kayu sengon-polyester (Rahman, Sudarisman, \& Nugroho, 2018) kayu kelapa-resin epoksi (Poyoh, Rauf, \& Lumintang, 2013) (Puja, 2010), kayu kamper-LDPE (Nurwendi et al., 2016), kayu jati-HDPE (Bootkul, Butkul, \& Intarasiri, 2017) pinus-PP (Gurau \& Ayrilmis, 2018), serat kulit durian (durian husk fibre)polystyrene (Chu et al., 2018), daun dan tangkai cabai-PP (Valles-Rosales, Rodríguez-Picón, Méndez-González, del Valle-Carrasco, \& Alodan, 2016), serat serabut kelapa-PVC (Rimdusit, Damrongsakkul, Wongmanit, Saramas, \& Tiptipakorn, 2011), limbah bongkaran konstruksi, CDW-HDPE (Hyvärinen, Ronkanen, \& Kärki, 2019). Mahoni-resin polyester (Gapsari \& Setyarini, 2010), mahoniPP (Vedat, 2020).

Adakalanya penambahan limbah serbuk gergaji pada plastik tidak secara spesifik menyebutkan jenis kayunya (Sudirman, Aloma, K.K., Ari Handayani, \& Hertinvyana, 2002). Penambahan serbuk kayu pada plastik dapat meningkatkan sifat mekanis seperti kekuatan impact (Bootkul et al., 2017)

Dua faktor penting penentu sifat fisik dan sifat mekanik WPC yaitu faktor material penyusun dan faktor proses. Faktor material penyusun diantaranya; jenis serbuk kayu, ukuran mesh, jenis plastik, penambahan serat penguat dan coupling agent. Faktor proses yaitu temperatur dan tekanan pencetakan. Menurut cliffer et.al $70 \%$ fraksi volume sebuk gergaji kelapa dengan mesh 250 merupakan persentase dan mesh terbaik untuk menghasilkan sifat mekanis optimum (Poyoh et al., 2013). Secara morfologi serbuk kayu yang halus lebih homogen dibanding sebuk yang kasar (Saptari, Sanjaya, \& Ghufran, 2016)

Selain plastik sebagai matriks dan serbuk kergaji kayu sebagai penguat, dapat ditambahkan serat lain untuk meningkatkan kekuatan WPC. Berbagai serat alam dapat digunakan seperti serat daun nanas (Hidayat, Yudo, \& Manik, 2016), serat akar wangi (Purwanto, 2016), serat pandan wangi (Yudhyadi \& Sari, 2013), serat sisal (Okariawan, Fajar, \& Hidayatullah, 2016), serat kelapa (Rimdusit et al., 2011), serat tangkai sagu (La Ode Mamur, Muhammad Hasbi, 2016). Persentase, diameter dan panjang serat dapat meningkatkan sifat mekanis sifat mekanis WPC (Sakinah, Bahruddin, \& Zultiniar, 2016). panjang serat optimum adalah antara $25 \mathrm{~mm}$ (Yudhyadi \& Sari, 2013) sampai 50mm (Sakinah et al., 2016)

Unsur penting lainnya dalam pembuatan WPC adalah coupling agent. Coupling agent berfungsi memperbaiki ikatan antara material matriks dan material reinforced sehingga sifat-sifat komposit jadi lebih baik (Prasetyo, Raharjo, \& Ubaidillah, 2013). Coupling agent juga dapat mencegah terbentuknya aglomerasi akibat dari serat dan matrik yang tidak tercampur secara merata. Jenis coupling agent yang dapat digunakan pada pembuatan WPC sangat beragam. Pemilihan coupling agent pada pembuatan WPC didasarkan pada pasangan jenis plastik dan reinforced-nya (natural fibre). Fenton $(\mathrm{H} 2 \mathrm{O} 2 / \mathrm{Fe} 2+)$ digunakan sebagai agen pengkopel komposit campuran kayu kamper dan LDPE (Nurwendi et al., 2016), Maleic anhydrid (MAH) digunakan sebagi agen pengkopel komposit campuran kayu pinus dan polypropylene (PP) (Gurau \& Ayrilmis, 2018).

Kadar serbuk kayu (wood flour) dan persentase MAPP memainkan peran penting terhadap density dan sifat mekanis (Vedat, 2020). Penamabahan coupling agent dapat meningkatkan kekuatan tarik, kekuatan bending dan kekuatan impact (Prasetyo et al., 2013), dan 
penurunan penyerapan kelembaban (Perisic et al., 2018)

Dalam penelitian ini dilakukan pengembangan WPC campuran plastik dan serbuk gergaji kayu. Serbuk gergaji kayu yang digunakan adalah kayu kelapa (coconut flour, $\mathrm{CFl)}$ mesh 30. Plastik yang digunakan adalah recylcle HDPE, (RHDPE) Sebagai penguat ditambahkan serat serabut kelapa (coconut fibre, $\mathrm{CF})$ dengan panjang antara 20-40 $\mathrm{mm}$. Pembuatan sampel menggunakan mesin hot press. Tujuan dari penelitian ini adalah untuk mendapatkan pengaruh persentasi komposisi serbuk gergaji, pengaruh variasi ukuran butir serta pengaruh variasi parameter proses (temperatur dan tekanan) terhadap sifat sifat mekanik WPC antara lain;

\section{METODE PENELITIAN}

Bahan-bahan utama yang digunakan dalam pembuatan WPC adalah: Serbuk gergaji kayu (SGK) kelapa, serat serabut kelapa (SSK), HDPE, coupling agent dan mold release wax

Tahapan pembuatan WPC sebagai sample uji dapar dilihat seperti gambar 1

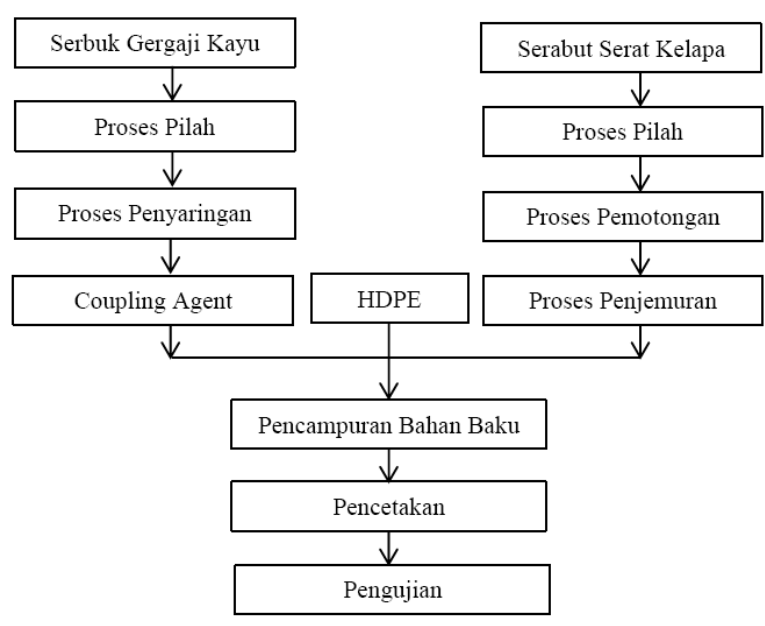

Gambar 1. Tahapan pembuatan sample

Serbuk gergaji kayu (SGK) dipilah menggunakan saringan mesh untuk mengetahui ukurannya. Serbuk gergaji kayu yang digunakan adalah jenis kayu kelapa yang diambil dari limbah penggergajain kayu. Ukuran mesh yang digunakan adalah mesh 10, mesh 20 dan mesh 30. Ukuran ini dipilih agar tidak dperlukan proses lain terhadap serbuk gergaji. Selanjutnya SGK dikeringkan untuk mengurangi kadar air.
Selain SGK, pada pembuatan WPC juga ditambahkan serat serabut kelapa (SSK). Setelah dipilah SSK dipotong dengan ukuran antara 2-4 $\mathrm{cm}$. selanjutnya SSK dikeringkan untuk mengurangi kadar air.

Diagram alir penelitian seperti terlihat pada gambar 2

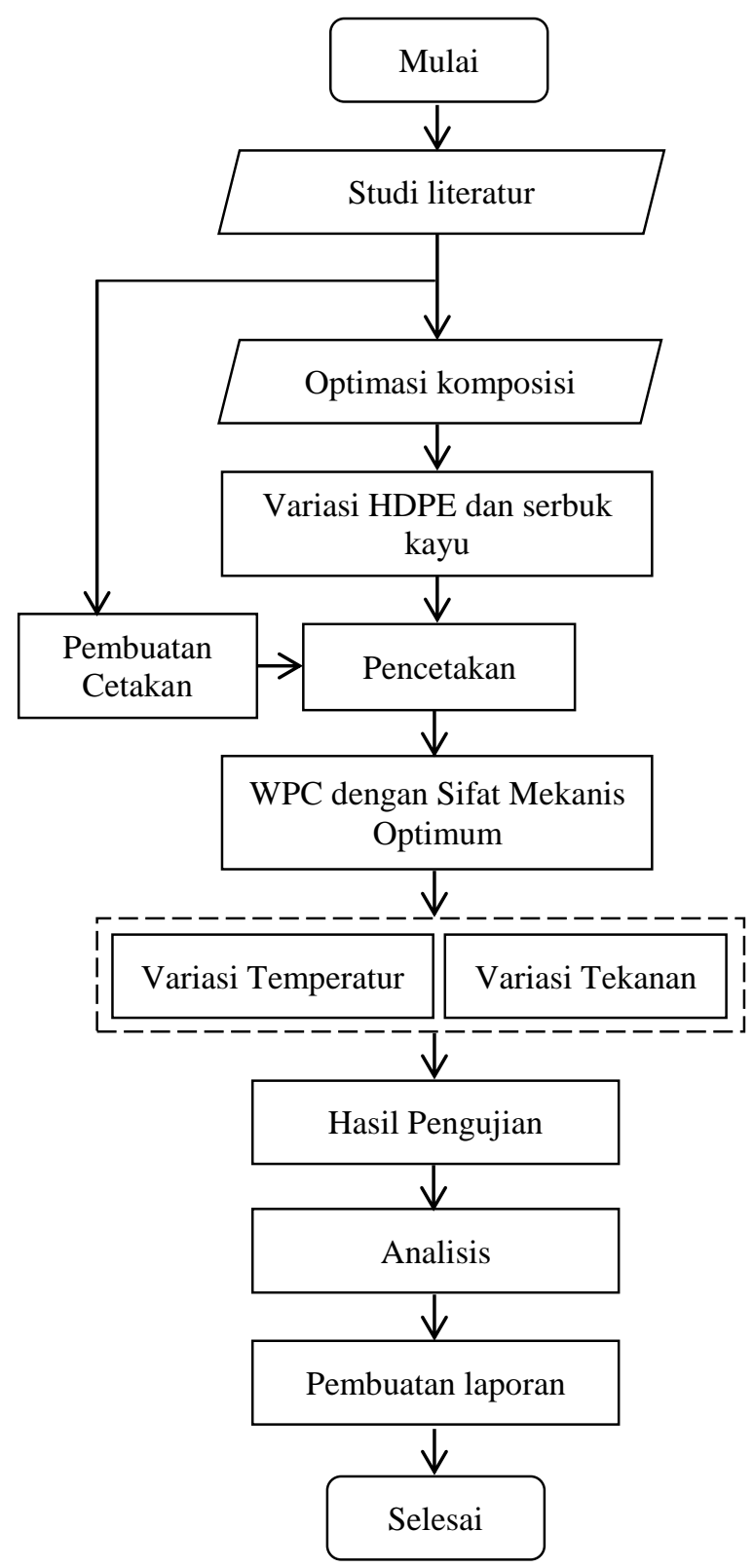

Gambar 2. Diagram Alir penelitian

Bahan-bahan utama (SGK, HDPE, SSK) yang telah disiapkan (gambar 3), kemudain dicampur dalam sebuah wadah dengan presentase seperti terlihat pada tabel 1 . 


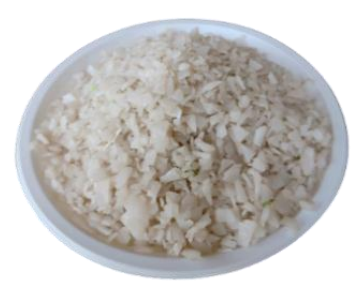

(a)

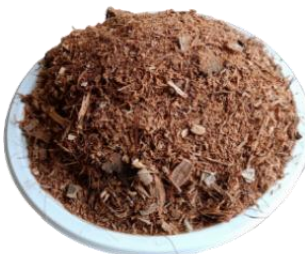

(b)

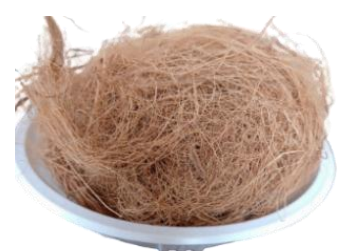

(c)

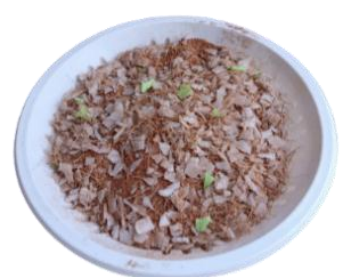

(d)

Gambar 3. Bahan utama pembuatan WPC (a) HDPE, (b) Serbuk Gergaji kayu (c) Serat serabut kelapa (d) bahan yang sudah dicampur

Tabel 1. Variasi komposisi WPC

\begin{tabular}{|c|c|c|c|c|c|c|}
\hline $\begin{array}{c}\text { Kode } \\
\text { Sample }\end{array}$ & $\begin{array}{c}\text { SGK } \\
\% \mathrm{wt}\end{array}$ & $\begin{array}{c}\text { HDPE } \\
\% \mathrm{wt}\end{array}$ & $\begin{array}{c}\text { SSK } \\
\% \mathrm{wt}\end{array}$ & Mesh & $\begin{array}{c}\text { Beban } \\
(\mathrm{kg})\end{array}$ & $\begin{array}{c}\text { Tek. } \\
\left(\mathrm{kg} / \mathrm{cm}^{2}\right)\end{array}$ \\
\hline 1 & 10 & 87 & 2 & 30 & 50 & 2.3 \\
\hline 2 & 20 & 77 & 2 & 30 & 50 & 2.3 \\
\hline 3 & 30 & 67 & 2 & 30 & 50 & 2.3 \\
\hline 4 & 20 & 77 & 2 & 20 & 50 & 2.3 \\
\hline 5 & 20 & 77 & 2 & 10 & 50 & 2.3 \\
\hline 6 & 20 & 77 & 2 & 30 & 75 & 3.4 \\
\hline 7 & 20 & 77 & 2 & 30 & 100 & 4.5 \\
\hline
\end{tabular}

Keterangan: SGK (Serbuk gergaji kelapa), SSK (serat serabut kelapa),

Proses pencetakan menggunakan mesin hot press (gambar 4). Mesin hot press yang digunakan memiliki kapasitas tekanan sampai 5ton dengan temperatur sampai $200^{\circ} \mathrm{C}$

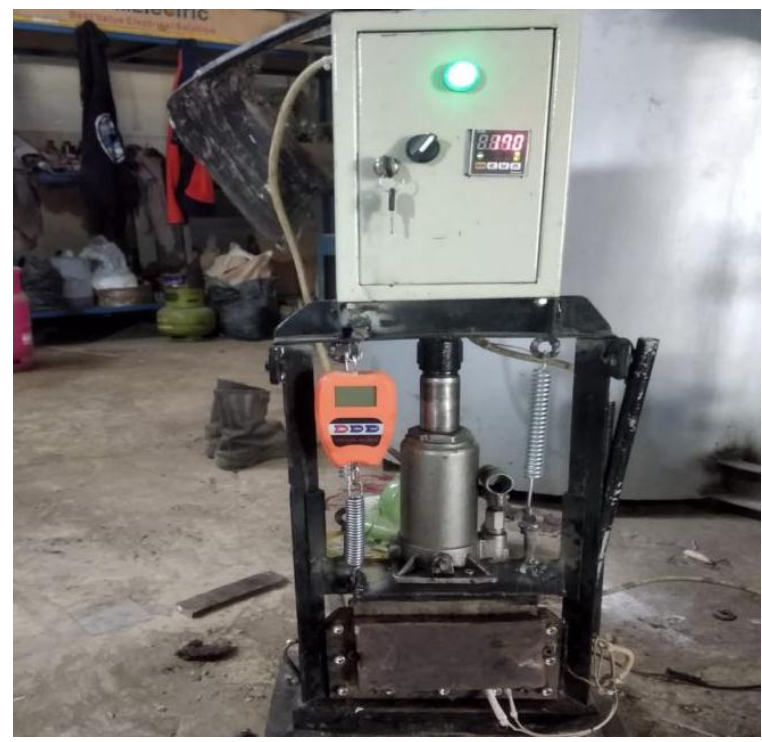

Gambar 4. Mesin hot press

Untuk mengetahui sifat mekanis dari komposit kayu-plastik, dilakukan pengujian tarik dan impak. Pengujain tarik menggunakan standar ASTM D638. Bentuk specimen uji tarik seperti terlihat pada gambar 5 .

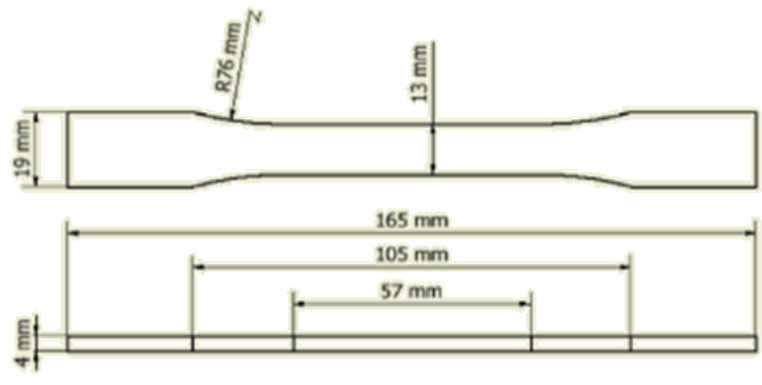

Gambar 5. Spesimen uji tarik

Pengujain Impak menggunakan standar ASTM D6110. Bentuk specimen uji impak seperti terlihat pada gambar 6 .

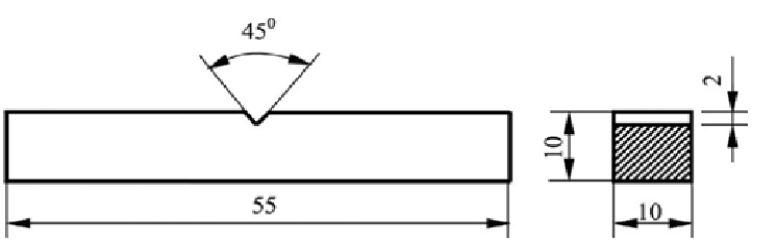

Gambar 6. Spesimen uji impak

\section{HASIL DAN PEMBAHASAN}

Pengaruh persentasi serbuk gergaji

Grafik pengaruh presentase serbuk gergaji terhadap kekuatan tarik seperti terlihat pada gambar 7. 


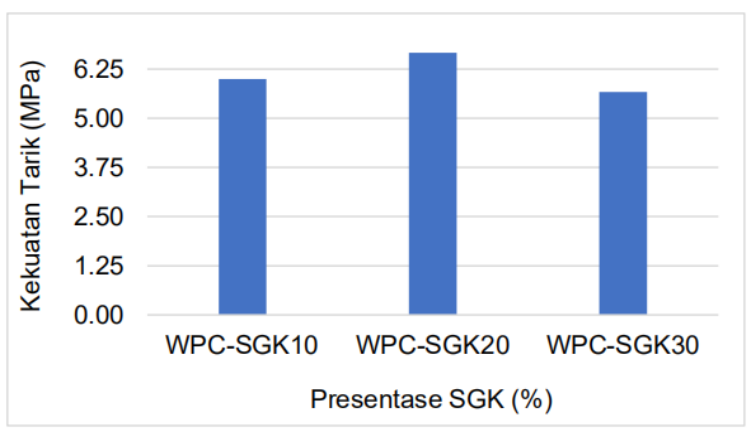

Gambar 7. Grafik pengaruh persentase serbuk gergaji terhadap kekuatan tarik

Dari grafik terlihat, secara umum penambahan sebuk gergaji meningkatkankan kekuatan tarik dari wpc. sampel wpc-sgk20 memiliki kekuatan tarik ratarata terbesar yaitu 6,67 MPa. Penambahan serbuk gergaji sampai $30 \%$ akan menurunkan kekuatan tarik.

Selain kekuatan tarik pengujian sifat mekanis lainnya adalah kekuatan impak. Grafik pengaruh presentase serbuk gergaji terhadap kekuatan impak seperti terlihat pada gambar 8 .

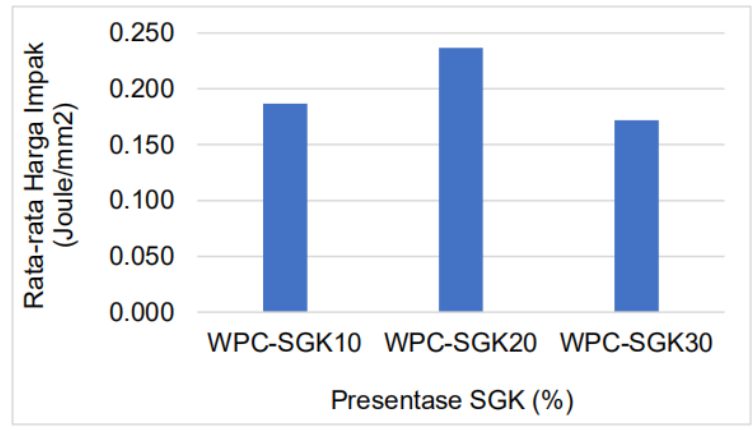

Gambar 8. Grafik pengaruh persentase serbuk gergaji terhadap harga impak

Sama seperti hasil pengujian tarik, harga impak terbesar terdapat pada sampel wpc-sgk20 yang memiliki harga rata-rata terbesar yaitu 0,237 Joule/mm². Penambahan serbuk gergaji akan menurunkan kekuatan tarik.

\section{Pengaruh tekanan terhadap sifat mekanis}

Sampel wpc dengan variasi tekanan seperti terlihat pada gambar 9 .

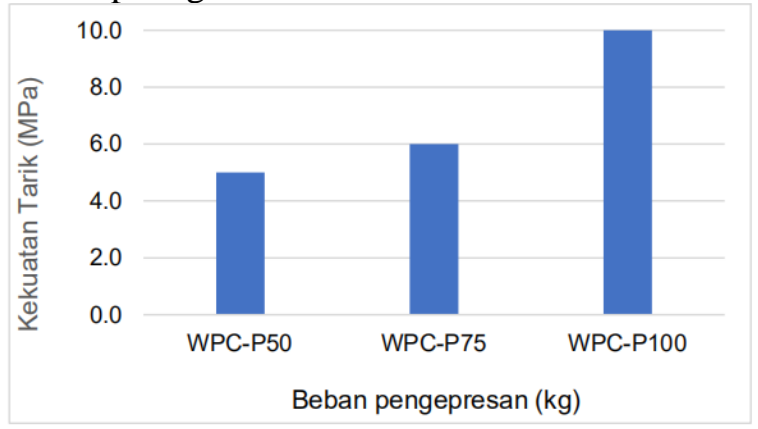

Gambar 9. Grafik pengaruh beban pengepresan terhadap kekuatan tarik
Dari grafik terlihat adanya pengaruh penambahan tekanan terhadap kekuatan tarik. Penambahan tekanan dapat meningkatkan kepadatan wpc. Tekanan yang tinggi dapat memperluas kontak antara plastik dan sebuk gergaji. Kekuatan tarik maksimum terdapat pada beban $100 \mathrm{~kg}$ atau pada tekanan $4.5 \mathrm{~kg} / \mathrm{cm}^{2}$, dengan nilai kekuatan tarik sebesar $10 \mathrm{MPa}$.

Pengaruh variasi tekanan terhadap harga impak seperti terlihat pada gambar 10 .

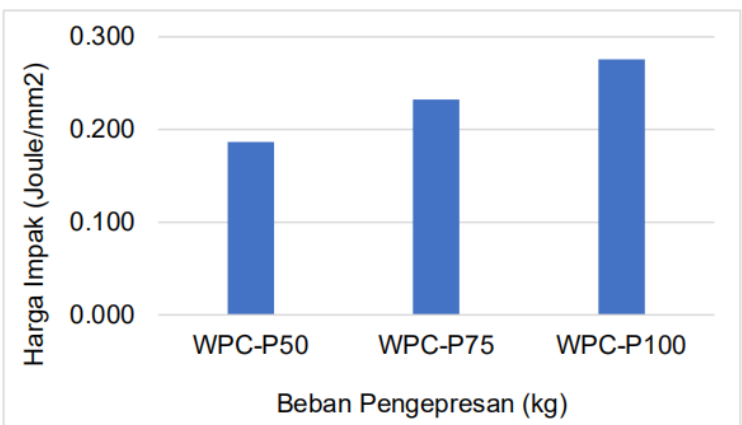

Gambar 10. Grafik pengaruh beban pengepresan terhadap harga impak

Dari grafik terlihat adanya pengaruh penambahan tekanan terhadap harga impak. Semakin padat sampel maka semakin besar energi yang dapat diserap. Harga impak tertinggi terdapat pada beban $100 \mathrm{~kg}$ atau pada tekanan $4.5 \mathrm{~kg} / \mathrm{cm}^{2}$, dengan harga impak sebesar 0.276 Joule $/ \mathrm{mm}^{2}$

\section{Pengaruh ukuran mesh}

Variasi ukuran mesh bertujuan untuk mengetahui pengaruh ukuran butir serbuk gergaji terhadap kekuatan mekanis. Ukuran mesh yang digunakan adalah \#30, \#20, dan \#10. Tujuan penggunaan mesh tersebut adalah agar tidak diperlukan perlakuan lain terhadap serbuk gergaji. Pada variasi mesh ini komposisi sampel yang digunakan adalah 20\% SGK. Hasil pengujian tarik sampel dengan variasi tekanan seperti terlihat pada gambar 11.

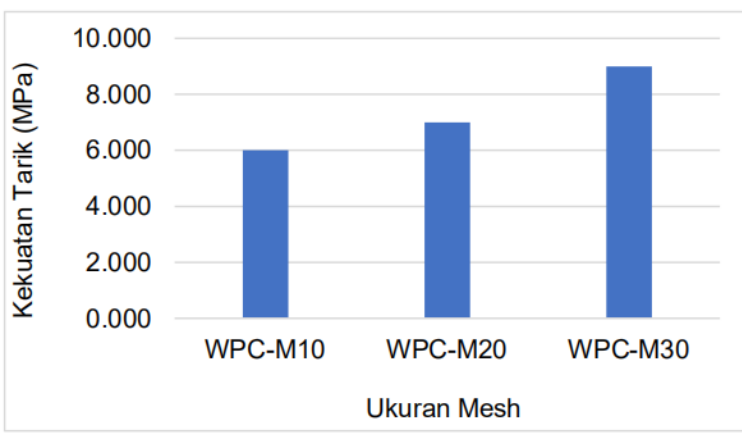

Gambar 11. Grafik pengaruh ukuran butir serbuk gergaji (mesh) terhadap kekuatan tarik 
Dari gambar terlihat kekuatan tarik meningkat seiring menurunnya ukuran butir serbuk gergaji. Kekuatan tarik terbesar diperoleh pada sampel WPCM30 yang memiliki mesh 30 yaitu sebesar $9 \mathrm{MPa}$.

Pengaruh variasi ukuran butir serbuk gergaji seperti terlihat pada gambar 12

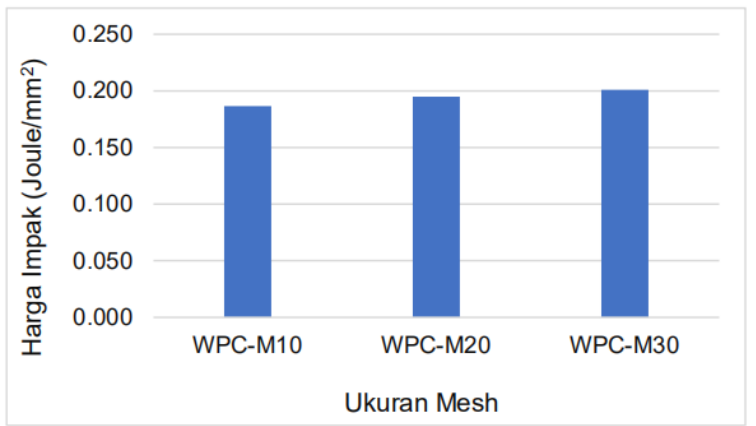

Gambar 12. Grafik pengaruh ukuran butir serbuk gergaji (mesh) terhadap harga impak

Sama seperti hasil pengujian tarik. Hasil pengujian impak menunjukan harga impak meningkat seiring menurunnya ukuran butir serbuk gergaji kayu. Harga impak tertinggi dihasilkan pada diperoleh pada sampel WPC-M30 yang memiliki mesh 30 yaitu sebesar 0,201 Joule/mm²

\section{Pengaruh Temperatur}

Temperatur pencetakan sangat berpengaruh terhadap kualitas hasil pencetakan (wpc). Penentuan temperatur pencetakan komposit berbeda dengan temperatur material secara tunggal. Temperatur yang rendah menyebabkan HDPE tidak mencair sehingga penyatuan material-material penyusun tidak homogen (gambar 12a). Jika temperatur terlalu tinggi akan menyebabkan peng-arang-an. Dimana material kayu akan menghitam menjadi arang (gambar 12b)

Selain temperatur yang tinggi penyebab terjadinya peng-arang-an adalah terlalu lamanya holding time. Holding time sangat bergantung pada tebal prodik yang kita cetak. Hal ini dikarenakan butuh waktu untuk bagian tengah dari komposit untuk mencapai temperatur yang sama dengan temperatur pada dinding bagian dalam dari cetakan. Serbuk gergaji akan berperan sebagai isolator. Temperatur optimum pada pembuatan wpc HDPE-Serbuk gergaji kayu kelapa ini tetap menggunakan temperatur leleh HDPE yaitu sebesar $125-130{ }^{\circ} \mathrm{C} \pm 20 \%$.

Diperlukan temperatur dan holding time yang sesuai untuk menghasilkan wpc dengan ke-cair-an HDPE yang seragam namun tidak menyebabkan serbuk gergaji menjadi arang. berdasarkan pemeriksaan visual, kualitas wpc yang baik dihasilkan pada temperatur $150^{\circ} \mathrm{C}$ dengan holding time selama 15 menit (gambar 12c)

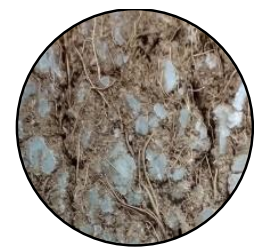

(a)

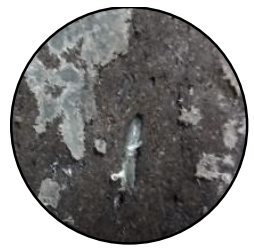

(b)

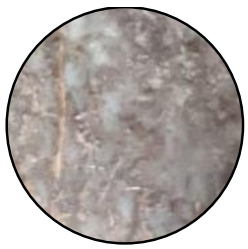

(c)
Gambar 12. Hasil pengamatan visual. (a) tekanan dan temperatur rendah (b) temperatur terlalu tinggi (c) temperatur optimum

\section{KESIMPULAN DAN SARAN}

Hasil beberapa kali percobaan, temperatur yang tepat untuk mencetak wpc pada penelitian ini adalah adalah $150^{\circ} \mathrm{C}$ dengan holding time 15 menit

Serbuk gergaji kayu berpengaruh terhadap peningkatan kekuatan tarik pada wpc. Namun setelah melewati titik jenuh, penambahan SGK akan menurunkan kekuatan tarik. Presentasi optimum dari wpc HDPE-Serbuk gergaji kayu kelapa dengan proses hot press didapat pada presentase 20\% SGK, dengan kekuatan tarik rata-rata terbesar yaitu 6.67 MPa. Kekuatan tarik minimun terdapat pada wpc dengan 30\%SGK yaitu sebesar 5,67 MPa. Harga impak maksimum terdapat pada wpc dengan presentase SGK 20\%. sebesar 0.237 Joule $/ \mathrm{mm}^{2}$ sedangkan harga impak terendah terdapat pada wpc dengan presentase $30 \%$ sebesar 0.172 Joule $/ \mathrm{mm}^{2}$.

Selain presentase SGK, tekanan pengepresan juga berpengaruh terhadap peningkatan kekuatan sifat mekanis. Hasil pengujian kekuatan tarik maksimum terdapat pada beban $100 \mathrm{~kg}$ atau pada tekanan $4.5 \mathrm{~kg} / \mathrm{cm}^{2}$, dengan nilai rata-rata kekuatan tarik sebesar $10 \mathrm{MPa}$ dan kekuatan tarik terendah terdapat pada tekanan $50 \mathrm{~kg}$ dengan nilai kekuatan tarik rata-rata sebesar $5 \mathrm{MPa}$. Harga impak tertinggi terdapat pada beban $100 \mathrm{~kg}$, dengan harga impak sebesar 0.276 Joule $/ \mathrm{mm}^{2}$. Harga impak terendah terdapat pada tekanan $50 \mathrm{~kg}$ yaitu sebesar 0.187 Joule $/ \mathrm{mm}^{2}$.

Ukuran butir serbuk gergaji kayu juga berpengaruh terhadap sifat mekanis wpc. Sifat mekanis meningkat seiring menurunnya ukuran butir serbuk gergaji kayu. Kekuatan tarik maksimum terdapat pada wpc dengan serbuk gergaji mesh 30 yaitu sebesar $9 \mathrm{MPa}$. Kekuatan tarik terendah terdapat pada wpc dengan serbuk gergaji mesh 10 yaitu sebesar $6 \mathrm{MPa}$. Harga impak tertinggi diperoleh pada wpc dengan serbuk gergaji mesh 30 yaitu sebesar $0,201 \mathrm{Joule} / \mathrm{mm}^{2}$. Harga impak terendah terdapat pada wpc dengan serbuk gergaji mesh 10 yaitu sebesar 0,187 Joule/mm². 


\section{UCAPAN TERIMA KASIH}

Terima kasih disampaikan kepada Kemenristek Dikti yang telah membiayai hibah penelitian ini melalui skema Penelitian Dosen Pemula tahun pelaksanaan 2020, melalui Surat keputusan Nomor: 8/E1/KTP/2020 dengan Nomor Kontrak: 035/SP2H/LTMONO/LL4/2020.Dilaksanakan melalui kontrak penelitian antara Rektor Universitas Ibn Khaldun dengan ketua Peneliti dengan No. 228/K.5/LPPM-UIKA/2020

\section{REFERENSI}

Bledzki, A. K., Mamun, A. A., \& Volk, Jü. (2010). Barley husk and coconut shell reinforced polypropylene: The effect fibre physical, chemical and surface properties. Composite Science and Technology, 70, 840-846.

Bootkul, D., Butkul, T., \& Intarasiri, S. (2017). Physical and Mechanical Properties of Wood Plastic Composites from Teak Wood Sawdust and High Density Polyethylene (HDPE). Key Engineering Materials, 751, 277-282.

Chu, K. S., Ratnam, C. T., Yeng, C. M., Subramaniam, V., Meng, P. M., Yeow, T. K., \& Ho, C. K. (2018). Wood plastic composites made from post-used. Journal of Thermoplastic Composite Materials, 20(10), $1-12$.

Gapsari, F., \& Setyarini, P. (2010). Pengaruh Fraksi Volume Terhadap Kekuatan Tarik Dan Lentur Komposit Resin Berpenguat Serbuk Kayu. Rekayasa Mesin, 1(2), 59-64.

Gurau, L., \& Ayrilmis, N. (2018). Effect of raw material composition of wood plastic composites on surface roughness parameter evaluated with a robust filtering method. Journal of Thermoplastic Composite Materials, 20(10), 1-15.

Hidayat, A., Yudo, H., \& Manik, P. (2016). Analisa Teknis Komposit Sandwich Berpenguat Serat Daun Nanas Dengan Core Serbuk Gergaji Kayu Sengon Laut Ditinjau Dari Kekuatan Tekuk Dan Impak. Jurnal Teknik Perkapalan, 4(1), 265-273.

Hyvärinen, M., Ronkanen, M., \& Kärki, T. (2019). The effect of the use of construction and demolition waste on the mechanical and moisture properties of a wood-plastic composite. Composite Structures, 210(April 2018), 321-326.
JR, J., Geyer, R., Chris Wilcox, C., RS, T., Perryman, M., Andrady, A., ... LL, K. (2015). Plastic waste inputs from land into the ocean. Science, 347(6223), 768-771.

La Ode Mamur, Muhammad Hasbi, P. A. (2016). Kajian Eksperimental Sifat Mekanik Material Komposit Kayu Jati. JENTHALPHY - Jurnal Ilmiah Mahasiswa Teknik Mesin, 2(2), 37-41.

Nurwendi, H., Simpen, I. N., \& Negara, I. M. S. (2016). Sintesis Komposit Selulosa Serbuk Gergaji Kayu Kamper-Limbah Plastik Ldpe (Low Density Poliethylene) Dengan Reagen Fenton Sebagai Agen Pengkopling. Jurnal Kimia, 10(1), 89-95.

Okariawan, I., Fajar, M., \& Hidayatullah, S. (2016). Optimasi kekuatan tarik komposit polyester diperkuat serat sisal dengan filler serbuk gergaji kayu sengon menggunakan metode respon surface. Dinamika Teknik Mesin, 6(2).

Perisic, S. D., Radovic, I., Petrovic, M., Marinkovic, A., Stojanovic, D., Uskokovic, P., \& Radojevic, V. (2018). Processing of hybrid wood plastic composite reinforced with short PET fibers. Materials and Manufacturing Processes, 33(5), 572-579. https://doi.org/10.1080/10426914.2017.136 4854

Poyoh, C. F., Rauf, F. A., \& Lumintang, R. (2013). Pengaruh Variasi Ukuran Butiran Filler Serbuk Gergaji Batang Kelapa Terhadap Sifat Mekanik Komposit. Jurnal Online, Poros Teknik Mesin, 2(1).

Prasetyo, D., Raharjo, W. W., \& Ubaidillah. (2013). Pengaruh penambahan coupling agent terhadap kekuatan mekanik komposit polyester-cantula dengan anyaman serat 3D angle interlock. Mekanika, 12(1), 44-52.

Puja, I. G. K. (2010). Studi Sifat Impak Ketahanan Aus dan Koefisien Gesek Bahan Komposit Arang Limbah Serbuk Gergaji Kayu Glugu Dengan Matrik Epoxy. Jurnal Ilmiah Teknik Mesin, CAKRAM, 4(2), 155159.

Purwanto. (2016). Komposit Serat Alam Akar Wangi Dan Limbah Serbuk Gergajian Kayu Sebagai Bahan Dasar Alternatif. Ethos, 4(2), 299-302.

Rahman, M. B. N., Sudarisman, S., \& Nugroho, E. (2018). Pengaruh Ukuran Butir, Fraksi Volume dan Penambahan Aseton terhadap Kekuatan Flexural Komposit Papan Partikel Serbuk Gergaji Kayu Sengon-Matrik 
Polyester. JMPM: Jurnal Material \& Proses Manufaktur, 2(2), 110-118.

Republika. (2018). KLHK: Produksi Sampah Nasional 65,8 Juta Ton per Tahun. Retrieved July 20, 2019, from Republika.co.id website: https://nasional.republika.co.id

Rimdusit, S., Damrongsakkul, S., Wongmanit, P., Saramas, D., \& Tiptipakorn, S. (2011). Characterization of coconut fiber-filled polyvinyl chloride/acrylonitrile styrene acrylate blends. Journal of Reinforced Plastics and Composites, 30(20), 16911702.

Sakinah, S., Bahruddin, \& Zultiniar. (2016). Pengaruh diameter dan panjang serat pelepah sawit terhadap sifat dan morfologi wood plastic composite (WPC). Jom FTeknik, 3(2), 1-8.

Saptari, S. A., Sanjaya, E., \& Ghufran, A. I. (2016). Pengujian Tingkat Kekerasan Bahan Komposit Serbuk Kayu dengan Matrik Resin Epoksi. Jurnal Al-Fiziya, 9(2), 74-80.

Slamet, S. (2013). Karakterisasi Komposit Dari Serbuk Gergaji Kayu ( Sawdust ) Dengan Proses Hotpress Sebagai Bahan Baku Papan Partikel. SNST Ke-4, 1-9.

Sudirman, Aloma, K.K., I. G., Ari Handayani, \& Hertinvyana, E. (2002). Sintetis dan karakterisasi komposit Polipropilena/Serbuk Kayu Gergaji. Jurnal Sains Materi Indonesia, 4(1), 20-25.

Valles-Rosales, D. J., Rodríguez-Picón, L. A., Méndez-González, L. C., del ValleCarrasco, A., \& Alodan, H. (2016). Analysis of the mechanical properties of wood-plastic composites based on agriculture chili pepper waste. Maderas: Ciencia y Tecnologia, $18(1), 43-54$.

Vedat, C. (2020). Selected Properties of Mahogany Wood Flour Filled Polypropylene Composites: The Effect of Maleic. Bio Resources, 15(2), 2227-2236.

Yudhyadi, I., \& Sari, N. H. (2013). Analisa Kekuatan Impact Komposit Polyester Diperkuat Serat Pandan Wangi dengan Pengisi Serbuk Gergaji Kayu. Jurnal Energi Dan Manufaktur, 6(2), 129-134. 